\title{
The Neo-Gramscian School to International Political Economy, Passive Revolution and Globalization*
}

\author{
Filipe Mendonça \\ Universidade Federal de Uberlândia, Brazil \\ Davi Demuner \\ Universidade Federal de Uberlândia, Brazil
}

(Ramos, Leonardo. Hegemonia, revolução passiva e globalização: o sistema G7/8. Minas Gerais: Editora PUC, 2013)

"Hegemonia, revolução passiva e globalização: o sistema G7/8", a book by Leonardo Ramos published in 2013 by Editora PUC Minas, outbreaks a central issue of the contemporary international system and, consequently, of International Relations as an independent field of study: the relationship between hierarchy, order and change. In fact, several traditions of the political and economic thought removed the inequality of power and conditions among social actors as well as external constraints from the analysis of the international scenario. For Ramos (2013), this was not different for the area of International Relations: neglecting the study of hierarquical relations is explained by the influence of the monumental work of Kenneth N. Waltz (2002).

While the gap generated by the work that originates the neorealism from the deep understanding of international economic relations is unquestionable, it is known that the same period also had a significant impact on other theoretical debates in the field of International Relations. Authors such as Robert Gilpin (2002), Paul Kennedy (1989), Giovanni Arrighi (1994), Eric Hobsbawm (1995), among others, when analyzed the events of the 1970s, characterized this situation as a 'systemic crisis'. In other words, each author, in his own way, understood that 
the US hegemony was in decline, and that this would generate disorder since it is the hegemonic country the one that has to regulate and therefore order the system. Many events contributed to this type of analysis: from the crisis of the Bretton Woods institutions in the 1960s, the Triffin dilemma and Gaullism, to the troubled scene of the 1970s, with the end of the dollar-gold convertibility in 1971 and of the commitment to the fixed exchange rate in 1973, the shocks of oil and the balance of US payments problems. In several dimensions, those authors argue, the United States lost authority. Although the US military power or the American ideological supremacy has not been questioned, and even though the dollar still holds a special condition today in relation to other currencies, it is clear that the $1970 \mathrm{~s}$ was a period of profound change.

This situation of economic crisis, besides reorganizing the operating rules of international economic relations with impact to the present day, has also contributed to the development of alternative thoughts in the area, such as the 'International Political Economy' (IPE). Although IPE never made up a cohesive group, it is widely recognized because it highlights the umbilical relationship between power and money, state and market, authority and economy. No wonder that the book by Leonardo Ramos (2013), in addition to being a good reflection on the G7/8 system, has become an important reference for the studies of IPE in Brazil. Although this field of study is an area in dispute, it is known that the tradition of thought chosen by Leonardo Ramos (2013) is quite efficient to capture the economic and political dynamics of the international scene, just by understanding those two manifestations of power as two faces of the same coin.

However, it is important to distinguish that different ways to understand the object of study can be identified in the history of IPE. The research agenda was initially stimulated by the works by authors such as Robert Keohane and Joseph Nye (1977), and Robert Gilpin (2002), who opened the space for the understanding of economic relations among states within the International Relations discipline. The influence of these authors had an impact on several new works, which were later consolidated in the United States as the American School of IPE. The quantitative models and the rigor of positivism served to consolidate the rationalist thought in the field, due to an approach close to Economics, which 
can also be seen by the expansion and influence of behaviorism in the social sciences (COHEN, 2008; SMITH et al., 1996).

The questionings about the American school model gained space with the contributions of Robert W. Cox (1983) and Stephen Gill (1990), among others, that stimulated the overflow of the analysis of the economic phenomena in the international arena, beyond the theoretical and empirical scope proposed by previous authors; this contributed to build a new line of thought in IPE. The latter two authors, for example, introduced new analytical tools, through the dialectical historical materialism of Marx, for understanding IR and therefore IPE, using Gramsci's work together with the emancipatory character of reason advocated by the Frankfurt School. Thus, the Gramscian concept of hegemony is reinterpreted to read the internationalization of production, and the maintenance of the agenda of international institutions favorable to the interests of the central states of the international economy.

This second line of thought of IPE, even with multiple internal differences, was the tradition chosen by Leonardo Ramos (2013), influenced by the aforementioned Robert W. Cox (1983) and Stephen Gill (1990), and William I. Robinson (2005), Morton Adam ( 2007) and John Agnew (2005), among others. These references make Ramos's book to consider, always in dialectical terms, the relationship between ideas, and material capacities and institutions; in addition, they make the book to more deeply consider the historical structures and their relation to certain situations, running away from determinisms and extreme voluntarisms.

This theoretical choice, besides challenging the mostly liberal mainstream of theories of international relations, seems more appropriate to deal with one of the central questions of the book: how to think about the relationship between hierarchy, order and change in contemporary world politics without leaving behind the processes of globalization? Note here two important faces of the problem raised by the author. First, the empirical observation of the phenomenon of globalization. Second, the election of hierarchy, order and change as fundamental axis for the research.

On the first issue, the author starts out from the empirical finding of important qualitative changes in social relations mainly observed from the 1970 s 
onwards, with increased speed and cross-border flows, the expansion of the decision-making core of international economic relations, and the multiplication of multilateralism of all kinds. If we stopped here, we would be very close to the liberal theses that defend a world without borders or to some most parsimonious readings of the theory of international regimes. However, the book by Leonardo Ramos (2013) teaches us, among other things, that identifying these aspects of reality does not necessarily mean a break with the undeniable centrality exercised by the United States in this phenomenon, and with the active role played by the State and other institutions. This questioning would not be possible outside IPE, which would push the analyst towards theses related to the end of the State (disregarding the active role of power and strength) or to classical imperialism (disregarding the new dynamics of global power).

Although seemingly simple to describe, several concepts have emerged in the IPE literature seeking to capture this aspect of reality: globalization, mundialization, interdependence, transnationalization, financialization, westernization, capital-imperialism, among others. Of all these, the first would perhaps be the most difficult to define. This is largely due to the polyssemic use of the term in the academic, political and economic debate. While recognizing all these problems, Leonardo Ramos (2013) uses the concept of globalization to describe this phenomenon. The concept is theoretically loaded, which can sometimes confuse the unwary reader. The author cites numerous possibilities of the concept's absorption in the contemporary debate: it can be conflated with globalization, liberalization, universalization, westernization and/or reespatialization.

Nevertheless, the author seeks to circumvent this problem by making a good theoretical and historical approach to the concept, and by precisely delineating what he calls Globalization Critical School (GCS). Although not central to the book's structure, this school seems to have given the tone of what will later become the inviolable axes for the arguments presented by Leonardo Ramos (2013): the necessity to break with the levels of analysis that put domestic and international as separate aspects of social reality; the need for historicizing international phenomena avoiding the mistakes of timelessness; the necessity to capture the material conditions and the inequalities arising from them; and, the 
urgency to break with exclusively Western readings of the globalization phenomenon.

On the second dimension (the election of hierarchy, order and change as fundamental axis for the research), the author chooses in Chapter 01, four major schools working with the assumptions of IPE -even though he later breaks with them-, which can be useful for understanding globalization and its impact on hierarchy, international order and the possibilities for change. They are: the studies on Global Governance; the studies on the New Imperialism; the studies on the Post-Modernity (divided into Empire and governmentability); and studies on the World-System.

It is not for us here to do a detailed analysis of each of these schools. It is sufficient to say that, for the author, though all of them have some merit in understanding some aspect of the contemporary reality, all of them are also insufficient because they disregard one or more aspects considered nonnegotiable for the analysis. The first of them, the very relevance and sophistication of the Globalization phenomenon (something overlooked by skeptics of globalization and by the statecentrists from the New Imperialism, System-World and governmentability schools); the second, the unquestioned permanence of the 'old Westphalian world', centrality of the state and of the power relations even in a global scenario (something overlooked in hyperglobalist readings of the Global Governance and the Empire schools); and third, the relevance of the territoriality and its specificities in the exercise of power and in the manifestation of the global order (something overlooked by the approaches of the Empire, the governmentability and the Global Governance).

In chapter 02, entitled "The Neogramscian prospects as an alternative proposal for the issue of order and change in the global political economy", Leonardo Ramos (2013) assumes that the only way to go forward in the analysis without breaking any of the aforementioned three guiding systemized axes is through the absorption and adaptation of Gramsci's work. After a detailed analysis of the classic Italian author's work, Leonardo Ramos (2013) concludes that only through a neogramscian reading it is possible to see "globalization as something real without, however, disregarding the state's role in this process" and, at the same time, to give "the necessary weight to the role played by the United States at

(2016) $10(3) \quad$ a $\quad$ e0010-5/8


the origin and at the consequences of this global power configuration process" (RAMOS, 2013, p. 137). In addition, by allowing to capture the new dynamics imposed by globalization without breaking with the forms and the centrality of the state, the author is part of a major debate of the neogramscian approach, since he reinforces the analysis of the internal social forces of the state, rejecting reductionisms regarding these forces' agency from readings that see the periphery of IPE as a 'transmission belt', and by doing so, the author also becomes an important interlocutor to this school in Brazil.

Chapters 03, 04 and 05 deal with the empirical part of the work, making a detailed analysis of the G7/8 system. For the author, this international institution, besides being the result of a specific liberal historical bloc, operates through networks in order to transnationalize part of the issues that were previously exclusive to States, and also adding substate and superstate entities with the sole purpose of watching, through a regulatory, and sometimes, coercive framework the liberal world as it is set up today. On the role played by the United States in the G7/8, even though the author acknowledges the almost unilateral role that this country has played inside the institution mainly in the 1970s and 1980s, he also asserts that this position has been changing. This finding does not mean that there are important questions of liberal order in the G7/8, but points out to the reality of globalization and its impact on the States, through the globalization of economic affairs.

The argument becomes especially interesting when it includes the G-20 into the equation, in the light of the concept of passive revolution. For the author, the expansion of the forum with the inclusion of peripheral countries never meant any kind of structural change. Thus, it is concluded that this extension to the G20, although implies molecular adjustments in this system, has the primary objective of maintaining the neoliberal model, but now perhaps at another level, in terms of legitimacy with a false appearance of representation of the developing world. At the same time, the expansion appears to be as a necessity with the deepening of globalization and the new challenges posed by the transnational nature of the economy.

Ramos (2013) shows that most of the time, the G20 endorses the position of the G7/8, while in others, remains neutral, which means, in our view, a 'light 
form' of endorsement, that always conducts to keeping the current power structure. The book takes us to think critically about the role of multilateralism in the contemporary order, so vaunted by the makers of Brazilian foreign policy, for example, as a solution to the flow of the guidelines of the peripheral countries. The author shows us the limits of this possibility without disregarding the important changes in the management of the liberal economic order that now operates in transnational levels.

Recognizing the need for studies on global society to overflow state borders to understand the phenomena provided by globalization, the importance of national aspects remains, but the forces originated by the capital transnationalization movement have global effects, that is, these are not limited to the local/regional. Global characteristics need to be studied to increase the knowledge of International Relations - mainly related to the differences in these times of relativization of the nation-state borders -, to understand how the homogenization of the forms of social organization operates, as well as how movements that emerge against this process work, as they might be progressive or simply antihegemonic. In this sense, Leonardo Ramos' work (2013) is a great contribution.

Translated by Robert McDonnell

\section{References}

AGNEW, John. A. (2005), Hegemony: The New Shape of Global Power. Philadelphia: Temple University Press. 284pp.

ARRIGHI, Giovanni. (1994), The Long Twentieth Century: Money, Power, and the Origins of Our Times. London/New York: Verso. 416pp.

COHEN, Benjamin J. (2008), International Political Economy: An Intellectual History. Princeton: Princeton University Press. 224pp.

COX, Robert W. (1983), Gramsci, hegemony and international relations: an essay in method. Cambridge Studies in International Relations, v. 26. 1983.

GILL, Stephen. (1990), Two concepts of international political economy. Review of International Studies. v. 16, pp. 369-381. 
GILPIN, Robert (2002), A economia política das relações internacionais. Brasília: Editora UnB. 493pp.

HOBSBAWM, Eric (1995), Era dos extremos: O breve século XX. São Paulo: Editora Companhia das Letras. 632pp.

KENNEDY, Paul M. (1989), The Rise and Fall of the Great Powers: Economic Change and Military Conflict from 1500 to 2000. New York: Harper Collins Paperback. 704pp.

KEOHANE, Robert. O and NYE, Joseph S. (1977), Power and interdependence: world politics in transition. Boston: Little, Brown and Company. 273pp.

MORTON, Adam D. (2007), Unravelling Gramsci: hegemony and passive revolution in the global political economy. London: Pluto Press. 272pp.

RAMOS, Leonardo C. S. (2013), Hegemonia, revolução passiva e globalização: o sistema G7/8. Belo Horizonte: Ed. PUC Minas. 384pp.

ROBINSON, William I (2005), Gramsci and Globalisation: From Nation-State to Transnational Hegemony. Critical review of international social and political philosophy. v.8, n.4, pp. 559-574.

SMITH, Steve; BOOTH, Ken and ZALEWSKI, Marysia. (1996), International Theory: Positivism and Beyond. Cambridge: Cambridge University Press. 362pp.

WALTZ, Kenneth. N. (2002), Teoria das relações internacionais. Lisboa: Gradiva. 344pp. 


\title{
brazilianpoliticalsciencereview
}

\section{E R R A T U M}

The Editor-in-Chief of the Brazilian Political Science Review manifests that the authorship of the book review entitled The Neo-Gramscian School to International Political Economy, Passive Revolution and Globalization, DOI: 10.1590/1981382120160002000010, published in the Brazilian Political Science Review Vol.10(3), on pages 01-08, was published with the omission of the name of one of its authors, due to a mistake at the time of sending the file. In the authorship of the article, the name of Davi Demuner must be Added and his institutional affiliation as Universidade Federal de Uberlândia, Brazil. The name and the institutional affiliation of the authors follow:

\section{The Neo-Gramscian School to International Political Economy, Passive Revolution and Globalization*}

\author{
Filipe Mendonça
}

Universidade Federal de Uberlândia, Brazil

Davi Demuner

Universidade Federal de Uberlândia, Brazil

* http://dx.doi.org/10.1590/1981-3821201700010020 